\title{
BETWEEN ONE PLACE AND ANOTHER
}

Sarah Roberts

First I will take off my shoes

First I will wash my feet

First I will salve swollen heat

First I will call you

First I will sit down, brush flies away

It will be hot there

It will be hot here

Next I will take time

Next I will take a moment

Next I will hold

The light will be late

Afternoon, the light will be

As in a tastefully-filmed movie

And it will be an arid region

And it will be on the border

Between one place and another

And flies will try to settle

Until we move from courtyard

Into cool space

And moving into cool space

We will be in shadow

I will bring you there

We will go there together

We will imagine white pine

We will see the trunk in its cape

We will see the cape open

We will see where the fire came through

We will see it stand, cape open,

Where the fire came through 